\title{
HUBUNGAN KONSUMSI WESTERN FAST FOODDENGAN HIPERTENSI PADA REMAJA DI SMA N 1 SEMARANG
}

\author{
Alfauzia Syafni, Hartanti Sandi Wijayanti *) \\ Program Studi Ilmu Gizi Fakultas Kedokteran Universitas Diponegoro \\ Jl.Dr.Sutomo No.18, Semarang, Telp (024) 8453708, Email : gizifk@undip.ac.id
}

\begin{abstract}
ABSTRACK
Background:Hypertension among adolescentshave to be considered because it has an effect for their health later. Earlierevaluationsneed to be conducted, such asto assessfood intake, especially western fast food. Western fast food contains high fat, sodium and low in fiber which could lead to hypertension ifitis consumedfrequently.

Objective: The aim of this study was to determine the correlationbetween western fast food consumption and hypertension amongadolescents in SMAN 1 Semarang.

Methods: This research usedcross sectional methodwith 45 subjects from SMA N 1 Semarangselected by simple random sampling. Western fast food intake was obtained through interviews using semi-quantitative food frequency questionnaireand assessed based on its frequency, portions, nutritional value, and contributionfor daily nutrition requirement. Blood pressure wasmeasured usingsphygmomanometer. Nutritional status was measured by anthropometry method included weight and height, and expressed as BMI/U Z-score. Bivariate analysis was performed using Rank Spearmantest.

Results: The prevalence of hypertension amongadolescentswas $6.66 \%$. A total of 10 subjects (22.2\%) consumed western fast food more than twice a week. The results showed that there was no correlation between western fast food consumption (frequency, portions, nutritional value, and contributionfor daily nutrition requirement) and hypertension ( $p>0.05)$.
\end{abstract}

Conclusion: there was no correlation between western fast food consumptionand hypertension among adolescents. Keywords: Western fast food, hypertension, adolescents

\section{ABSTRAK}

Latar Belakang : Hipertensi pada remaja perlu diperhatikan karena dapat mempengaruhi kesehatan ketika dewasa. Salah satu evaluasi dini yang perlu dilakukan adalah mengetahui konsumsi makan remaja, terutama western fast food. Western fast food mengandung tinggi lemak, natrium dan rendah serat yang berpotensi menimbulkan hipertensi jika dikonsumsi dengan frekuensi sering.

Tujuan : Mengetahui hubungan konsumsi western fast food dengan hipertensi pada remaja di SMA N 1 Semarang Metode : Desain penelitian ini adalah cross sectionaldengan jumlah subyek 45 orang. Subyek adalah remaja SMA $N$ 1 Semarang yang dipilih dengan simple random sampling. Data konsumsi western fast food dinilai dari frekuensi, porsi, kandungan gizi dan kontribusi terhadap pemenuhan kebutuhan sehari yang diperoleh melalui wawancara dengan menggunakan kuesioner food frequencysemi-quantitative. Tekanan darah diperiksa dengan Sphygmomanometer. Status gizi diukur berdasarkan antropometri meliputi berat badan dan tinggi badan yang dinyatakan sebagai Z-score IMT/U. Analisis bivariat menggunakan uji rank spearman.

Hasil : Prevalensi hipertensi pada remaja adalah sebesar 6,66\%. Sebanyak 10 subjek (22,2\%) mengonsumsi western fast food lebih dari 2 kali/minggu. Hasil penelitian menunjukkan bahwa tidak ada hubungan antara frekuensi, porsi, kandungan gizi dan kontribusi western fast food dengan kejadian hipertensi ( $p>0,05)$.

Simpulan : tidak ada hubungan antara konsumsi western fast food dengan hipertensi pada remaja. Kata Kunci :Western fast food, hipertensi, remaja

\section{PENDAHULUAN}

Hipertensi masih tetap menjadi masalah hingga saat ini karena beberapa hal, seperti meningkatnya prevalensi hipertensi dan adanya komplikasi yang dapat meningkatkan morbiditas dan mortalitas. ${ }^{1}$ Hipertensi dapat menimbulkan kerusakan lebih berat seperti stroke, penyakit jantung koroner serta penyempitanbilik kiri.Selain penyakit-penyakit tersebut, hipertensi dapat pula menyebabkan gagal ginjal dan diabetes mellitus.. ${ }^{4}$ Hipertensi memiliki sifat"silent killer" yang sering tanpa gejala tetapi berdampak negatif atau dapat membunuh karena disebabkan oleh serangan jantung. ${ }^{5}$

Hipertensi tidak hanya terjadi pada orang dewasa maupun lansia, namun juga pada remaja. Prevalensi hipertensi di Indonesia cukup tinggi, yaitu sebesar $25,8 \%$ pada tahun $2013 .{ }^{6}$ Berdasarkan laporan dari Dinas Kesehatan Provinsi Jawa Tengah tahun 2009, kasus tertinggi hipertensi ada di kota Semarang yaitu sebesar $29,6 \%$ dan pada tahun 2010 terjadi peningkatan menjadi $34,1 \%{ }^{7}$ Prevalensi kasus hipertensi remaja di Jawa Tengah mengalami peningkatan dari1,87\% pada tahun 2007 menjadi

${ }^{*}$ Penulis Penanggungjawab 
2,02\% pada tahun 2008. Di kota Semarang prevalensi hipertensi pada remaja tahun 2009 terjadi sebanyak 164 kasus $(6,01 \%){ }^{7}$ sedangkan pada tahun 2013 angka kejadian hipertensi sebesar $8,7 \% .^{8}$

Faktor-faktor yang mempengaruhi terjadinya hipertensi dibagi dalam dua kelompok besar yaitu faktor yang tidak dapat dimodifikasi seperti jenis kelamin, umur, genetik dan faktor yang dapat dimodifikasi seperti pola makan, kebiasaan olah raga, dan kebiasaan merokok. ${ }^{9}$ Berdasarkan hasil penelitian,pola makan dengan frekuensi sering mengonsumsi makanan yang mengandung tinggi energi, natrium, lemak jenuh dan rendah serat dapat meningkatkan risiko hipertensi. ${ }^{10,11,12}$ Kandungan zat gizi tersebut terdapat pada westernfast food atau makanan cepat saji, sehingga perlu perhatian lebih terhadap konsumsi western fast food. ${ }^{17}$

Konsumsi energi yang tinggi dapat berpengaruh terhadap obesitas, dimana orang yang menderita obesitas dapat berpotensi terjadinya hipertensi. ${ }^{13}$ Konsumsi natrium tinggi dapat menyebabkan tubuh meretensi cairan yang dapat meningkatkan volume darah. Konsumsi natrium tinggi juga dapat mengecilkan diameter arteri, akibatnya jantung harus memompakeras untuk mendorong volume darah melalui ruang yang semakin sempit, sehingga tekanan darah menjadi naik dan mengakibatkan hipertensi. ${ }^{14}$ Lemak jenuh dapat menyebabkan hipertensi melalui mekanisme dislipidemia. ${ }^{10}$ Dislipidemia merupakan salah satu faktor risiko aterosklerosis, dimana aterosklerosismeningkatkan resistensi pembuluh darahmenyebabkan denyut jantung meningkat, meningkatkan volumedarah yang berdampak pada peningkatan tekanan darah. ${ }^{15}$ Secara teori, asupan serat yang rendah mengakibatkan asam empedu lebih sedikit diekskresi feses, sehingga banyak kolesterol yang diabsorpsi dari hasil sisa empedu. Hal ini mengakibatkan banyak kolesterol beredar dalam darah dan menyebabkan penumpukan lemak di pembuluh darah yang dapat menghambat aliran darah sehingga berdampak pada peningkatan tekanan darah. ${ }^{16}$

Pola hidup pada remaja saat ini mengalami pergeseran, yaitu salah satunya ditandai para remaja senang mengonsumsi westernfast food..$^{18}$ Mereka menggemari western fast foodkarena pelayanannya cepat, rasanya enak, harga yang ditawarkan terjangkau dan makanan westernfast food sesuai dengan selera mereka. ${ }^{19}$ Western fast food dapat dengan mudah ditemukan di restoran atau cafe. Maraknya restoranwesternfast food membuat remaja lebih menggemari untuk mengkonsumsi makanan westernfast food dibanding makanan tradisional. ${ }^{20}$

Hasil penelitian yang dilakukan di Yogyakarta tahun 2007 pada subjek berusia 20-30 tahun, menunjukkan bahwa sebesar $42,9 \%$ subyek memiliki kebiasaan mengkonsumsi western fast food dan berisiko 1,44 kali untuk menderita hipertensi. ${ }^{21}$ Mengingat remaja sekarang banyak yang menggemari western fast food, maka identifikasi dini hipertensi pada remaja perlu dilakukan untuk mencegah penyakit degeneratif dalam jangka panjang. Hal ini dikarenakan hipertensi seringkali tidak disertai dengan gejala dan remaja yang menderita hipertensi dapat terus berlanjut pada usia dewasa. ${ }^{22}$ Berdasarkan hal tersebut maka peneliti tertarik untuk melakukan penelitian tentang "hubungan konsumsi westernfast food dengan hipertensi pada remaja."

\section{METODE PENELITIAN}

Penelitian ini dilaksanakan di SMA Negeri 1 Semarang pada bulan Mei 2015. Penelitian ini termasuk lingkup gizi masyarakat dan merupakan studi observasional dengan desain cross sectional.

Populasi pada penelitian ini adalah seluruh siswa kelas X dan XI sejumlah 792siswa. Jumlah subjeksebanyak 45 orang dihitung menggunakan rumus sampel korelasi dengan metode pengambilan subjek simple random sampling. Pengambilan subjek sebanyak 45 orang diawali dengan melakukan skrining. Skrining dilakukan untuk menyaring subjek yang sesuai dengan kriteria inklusi yaitu berusia 15-17 tahun, tidak merokok tidak mengonsumsi alkohol, dan tidak mengonsumsi obat-obatan. Skrining dilakukan dengan cara mewawancarai siswa dengan menggunakan kuesioner.

Data yang dikumpulkan dalam penelitian ini adalah data umum subjek, data antropometri, data konsumsi western fast food, dan data tekanan darah. Data umum subjek diperoleh dari wawancara dengan menggunakan kuisioner penelitian. Data antropometri meliputi berat badan subjek diukur menggunakan timbangan digital dengan kapasitas $150 \mathrm{~kg}$ dan ketelitian $0,1 \mathrm{~kg}$, sedangkan pengukuran tinggi badan menggunakan microtoise dengan kapasitas $200 \mathrm{~cm}$ dan ketelitian $0,1 \mathrm{~cm}$. Data konsumsi western fast food dinilai berdasarkan frekuensi, porsi, kandungan gizi dan kontribusi gizi western fast food terhadap pemenuhan kebutuhan sehari. Data frekuensi western fast food diperoleh dari hasil rata-rata seberapa sering subjek mengkonsumsi western fast food dalam seminggu, data porsi diperoleh dari rata-rata porsi western fast food yang dikonsumsi subjek dalam seminggu, data 
kandungan gizi diperoleh dari rata-ratakandungan giziwestern fast food per hari, dan data kontribusi western fast food diperoleh dari rata-rata kandungan gizi western fast food dibandingkan dengan total kebutuhan sehari dikali seratus persen. Data tekanan darah diperoleh menggunakan sphygmomanometer air raksa. Hasil pengukuran tekanan darah yang diperoleh kemudian dibandingkan dengan tabel tekanan darah anak laki-laki dan perempuan berdasarkan usia dan persentil tinggi badan.Pengukuran tekanan darah dilakukan sekali. Apabila pada pengukuran pertama ditemukan tekanan darah > persentil 90, maka dilakukan pengukuran ulang tekanan darah sebanyak dua kali pada kunjungan berikutnya di tempat yang sama, dan hasil pengukuran yang digunakan adalah rerata tekanan darah sistolik dan diastolik dari 3 kali pengukuran.Remaja dikatakan menderita hipertensi jika nilai rata-rata tekanan darah sistolik dan atau diastolik lebih dari persentil ke-95 berdasarkan jenis kelamin, usia, dan tinggi badan. ${ }^{23}$ Pengukuran tekanan darah dilakukan oleh perawat yang sudah terlatih.

Pengolahan dan analisis data dilakukan dengan program komputer.Analisis univariat digunakan untukmendeskripsikandistribusi frekuensi, rerata, standar deviasi,nilai minimal, maksimal dan median semua variabel yang diambil.Analisis bivariat digunakan untuk mengetahui hubungan konsumsi western fast food dengan hipertensi pada remaja. Analisis bivariat diawali dengan uji kenormalan data dengan menggunakan uji Saphiro Wilk. Uji rank spearmandigunakan untuk menguji hubungan konsumsi western fast food dengan hipertensi pada remaja.

\section{HASIL PENELITIAN}

Berdasarkan hasil penelitian, jenis western fast food yang paling banyak dikonsumsi oleh remaja adalah fried chicken sebanyak 42 orang $(93,33 \%)$. Jenis western fast food lain yang juga dikonsumsi oleh remaja yaitu beef steak sebanyak 24 orang $(53,33 \%)$, pizza sebanyak 19 orang $(42,22$ $\%)$, cheese burger sebanyak 15 orang (33,33\%), french fries sebanyak 9 orang (20\%), dan spaghetti sebanyak 6 orang $(13,33 \%)$. Sebanyak $51 \%$ subjek memilih mengonsumsi western fast food karena ikut teman dan $31 \%$ subjek memilih western fast food karena pelayanannya cepat dan rasanya enak. Sisanya $18 \%$ memilih mengkonsumsi western fast food karena sesekali ingin mencoba.

Berdasarkan hasil penelitian, subjek berjenis kelamin perempuan lebih banyak dibanding dengan laki-lakiyaitu sebanyak 28 orang $(62,2 \%)$. Subjek yang tidak memiliki riwayat keluarga hipertensi lebih banyak dibanding yang memiliki riwayat keluarga yaitu sebanyak 53,3 \%. Subjek yang menderita hipertensi yaitu sebanyak 3 orang $(6,67$ $\%)$. Subjek yang memiliki statusgizi lebihsebanyak 8 orang $(7.8 \%)$, sedangkan gizi kurang sebanyak 1 orang $(2.2 \%)$. Frekuensi subjek yang mengkonsumsi western fast food lebih dari 2 kali seminggu yaitu sebanyak 10 orang $(22,2 \%)$.

Tabel 1. Karakteristik Subjek Penelitian

\begin{tabular}{llcc}
\hline & & Frekuensi & \% \\
\cline { 3 - 4 } Jenis kelamin & Laki-laki & 17 & 37,8 \\
Riwayat keluarga hipertensi & 28 & 62,2 \\
& Perempuan & 14 & 31,1 \\
& Ya & 24 & 53,3 \\
Klasifikasi tekanan darah & Tidak & 7 & 15,6 \\
& Tidak tahu & 3 & 6,6 \\
& Prehipertensi & 3 & 6,6 \\
Klasifikasi Status Gizi & Hipertensi & 39 & 86,6 \\
& Tidak hipertensi & 1 & 2,2 \\
Klasifikasi aktivitas fisik & Status gizi kurang & 36 & 80,0 \\
& Status gizi baik & 8 & 7,8 \\
Frekuensi konsumsi western fast & Status gizi lebih & 39 & 86,6 \\
food & Ringan & 6 & 13,3 \\
& Sedang & 0 & 0,0 \\
& Tinggi & 10 & 22,2 \\
\hline
\end{tabular}

Berdasarkan tabel 2, rata-rata usia subjek yaitu 16 tahun. Rata-rata Z-score IMT/U pada subjek yaitu $-0,07$ yang berarti kategori gizi baik.
Median tekanan darah sistolik pada subjek yaitu 110 $\mathrm{mmHg}$ dan tekanan darah diastolik $70 \mathrm{mmHg}$. 
Tabel 2. Gambaran Usia, Z-score, Tekanan Darah Sistolik dan Diastolik Subjek

\begin{tabular}{lcclc}
\hline \multicolumn{1}{c}{ Karakteristik Subjek } & Median & Min & Max & Mean \pm SD \\
& & & & \\
\hline Usia & - & 15,20 & 17,80 & $16,54 \pm 0,63$ \\
Z-score IMT/U & - & $-2,60$ & 2,74 & $-0,07 \pm 1,28$ \\
Tekanan darah sistolik & 110,00 & 90,00 & 140,00 & - \\
Tekanan darah diastolik & 70,00 & 60,00 & 88,00 & - \\
& & & & \\
\hline
\end{tabular}

Konsumsi frekuensi western fast food pada subjek tidak lebih dari 1 kali per minggu yaitu sebesar 0,75. Porsi konsumsi bervariasi dari 0,04 6 porsi/minggu dengan median2 porsi. Kandungan gizi dan kontribusi western fast food hanya menyumbang sedikit terhadap kebutuhan sehari yaitu tidak lebih dari $10 \%$ kecuali pada natrium $16,37 \%$

Tabel 3. Gambaran frekuensi, porsi, kandungan gizi dan kontribusiwestern fast food

Hasil uji korelasi menunjukkan tidak ada hubungan antara frekuensi, porsi, kandungan gizi western fast food (energi, lemak, natrium dan serat) natrium dan serat)dengan tekanan darah sistolik maupun diastolik dengan $p>0,05$. Ada hubungan antara IMT z-score dengan tekanan darah diastolik

\begin{tabular}{llcc}
\hline \multicolumn{1}{c}{ Variabel } & Minimal & Maksimal & Median \\
\hline Frekuensi(kali/minggu) & 0,04 & 5,00 & 0,75 \\
Porsi & 0,04 & 6,00 & 2,00 \\
Kandungan gizi & 3,70 & 307,60 & 98,90 \\
Energi (kkal) & 0,20 & 20,00 & 5,80 \\
Lemak (gr) & 0,00 & 1,40 & 0,20 \\
Serat (gr) & 0,60 & 809,90 & 163,40 \\
Natrium (mg) & & \\
Kontribusi & 0,30 & 20,46 & 4,86 \\
Kontribusi energi (\%) & 0,59 & 36,60 & 7,88 \\
Kontribusi lemak (\%) & 0,06 & 68,05 & 16,37 \\
Kontribusi natrium (\%) & 0,00 & 18,92 & 1,29 \\
Kontribusi serat (\%) & & & \\
\hline
\end{tabular}

dan kontribusi western fast food (energi, lemak, dengan $\mathrm{p}<0,05$.

Tabel 4. Hubungan antara konsumsi western fast food, IMT z-score dengan tekanan darah

\begin{tabular}{|c|c|c|c|c|}
\hline \multirow[t]{2}{*}{ Variabel } & \multicolumn{2}{|c|}{ Tekanan darah sistolik } & \multicolumn{2}{|c|}{ Tekanan darah diastolik } \\
\hline & $\mathbf{r}$ & $\mathbf{p} \mathbf{r}$ & & \\
\hline 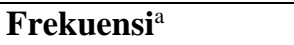 & $-0,14$ & 0,35 & $-0,2$ & 0,15 \\
\hline Porsi $^{\mathrm{a}}$ & $-0,12$ & 0,39 & $-0,16$ & 0,29 \\
\hline \multicolumn{5}{|l|}{ Kandungan gizi } \\
\hline Asupan energi ${ }^{\mathrm{a}}$ & $-0,16$ & 0,27 & 0,19 & 0,20 \\
\hline Asupan lemak ${ }^{\mathrm{a}}$ & $-0,15$ & 0,27 & 0,22 & 0,16 \\
\hline Asupan serat ${ }^{\mathrm{a}}$ & $-0,06$ & 0,69 & 0,03 & 0,83 \\
\hline Asupan natrium ${ }^{\mathrm{a}}$ & $-0,20$ & $-0,17$ & 0,20 & 0,18 \\
\hline \multicolumn{5}{|l|}{ Kontribusi gizi } \\
\hline Kontribusi energi ${ }^{\mathrm{a}}$ & 0,19 & 0,19 & 0,22 & 0,15 \\
\hline Kontribusi lemak ${ }^{\mathrm{a}}$ & $-0,12$ & 0,42 & 0,17 & 0,27 \\
\hline Kontribusi serat ${ }^{\mathrm{a}}$ & $-0,00$ & 0,99 & 0,09 & 0,54 \\
\hline Kontribusi natrium ${ }^{\mathrm{a}}$ & $-0,04$ & 0,99 & $-0,01$ & 0,94 \\
\hline IMT z-score & 0,21 & 0,15 & 0,30 & 0,04 \\
\hline
\end{tabular}

${ }^{\mathrm{a} U j i ~ k o r e l a s i ~ r a n k ~ s p e a r m a n ~}$

\section{PEMBAHASAN}

Prevalensi remaja yang menderita hipertensi menurut Riskesdas pada tahun $2013 \mathrm{di}$ kota Semarang sebanyak $8,7 \%$. Pada penelitian ini menunjukkan bahwa prevalensi remaja di SMA N 1
Semarang yang menderita hipertensi sebanyak $6,66 \%$. Hal ini menunjukkan bahwa prevalensi hipertensi di SMA N 1 Semarang lebih rendah jika dibandingkan data Riskesdas pada tahun 2013. Prevalensi status gizi lebih pada penelitian ini 
sebesar 7,8\% juga lebih rendah jika dibandingkan prevalensi gizi lebih berdasarkandata Riskesdas pada tahun 2013 sebanyak 8,8 \%. ${ }^{8}$ Menurut sebuah penelitian, seseorang yang memiliki berat badan lebih $20 \%$ dari normal memiliki resiko 2 kali lebih besar menderita hipertensi dibanding dengan orang yang normal. ${ }^{24}$ Prevalensi hipertensi yang rendah pada penelitian iniberkaitan dengan prevalensi gizi lebih yang juga rendah. Penelitian ini membuktikan ada hubungan secara bermakna antara status gizi dengan tekanan darah diastolik, dimana status gizi dengan tekanan darah juga memiiki korelasi positif.

Frekuensi western fast food pada subjek dengan kategori sering sebanyak 22,2\%. Frekuensi western fast food yaitu 0,75 kali per minggu. Hasil uji bivariat menunjukkan bahwatidak ada hubungan bermakna antara frekuensi western fast food dengan tekanan darah sistolik dan diastolik. Berdasarkan hasil penelitian, frekuensi western fast food yang sering dapat menimbulkan hipertensi. ${ }^{25}$ Pada penelitian ini frekuensi western fast food tidak berhubungan dengan hipertensi pada remaja. Hal ini disebabkan karena frekuensi konsumsi pada subjek tergolong jarang yaitu hanya 0,75 kali per minggu. Hasil penelitian yang sama yang dilakukan di Semarang menunjukkan bahwa tidak ada hubungan kebiasaan konsumsi western fast food dengan tekanan darah dengan rerata konsumsi 1,13 kali. ${ }^{26}$

Rata-rata konsumsi porsiwestern fast food pada remajayaitu2 porsi dalam seminggu.Hasil uji bivariat porsi western fast food dengan tekanan darah sistolik dan diastolik pada remaja menunjukkan tidak ada hubungan bermakna. Penelitian di Amerika menunjukkan bahwa seseorang yang mengonsumsi western fast food dengan porsi besar dan dengan frekuensi 2-3 kali/minggu dapat mengakibatkan hipertensi. ${ }^{27}$ Sedangkan pada penelitian ini hanya 2 porsi dengan frekuensi jarang, sehingga tidak berpengaruh terhadap hipertensi.

Kandungan energi pada western fast food yang dikonsumsi subjek rata-rata hanya 98,90 $\mathrm{kkal} / \mathrm{hari}$. Menurut sebuah penelitian di Cirebon kandungan energi western fast food $\geq 244 \mathrm{kkal}$ per hari merupakan faktor resiko obesitas, dimana seseorang yang memiliki obesitas dapat berpotensi menderita hipertensi. ${ }^{13}$ Pada penelitian ini, hasil uji bivariat tidak menunjukkan adanya hubungan bermakna antara kandungan energi western fast food dengan hipertensi pada remaja. Hal ini disebabkan rata-rata kandungan energi western fast food yang dikonsumsi masih cukup rendah.Kandungan energi western fast food yang rendah ini akan mempengaruhi kontribusi energi western fast food terhadap kebutuhan sehari yang juga rendah. Rata-rata kontribusi energi western fast food yaitu 4,86 \%. Hasil uji bivariat kontribusi energi western fast food menunjukkan bahwa tidak ada hubungan bermakna dengan tekanan darah sistolik maupun diastolik.

Kandungan lemak pada western fast food yang dikonsumsi subjek berkisar antara $0,2-20$ gr/hari dengan median 5,8 gr/hari. Hasil uji bivariat menunjukkan bahwa tidak ada hubungan bermakna dengan tekanan darah sistolik maupun diastolik. Total asupan lemak yang menderita hipertensi jika di rata-rata melebihi total yang dianjurkan yaitu $39,6 \%$. Secara teori, konsumsi lemak jenuh dapat menyebabkan hipertensi melalui mekanisme dislipidemia. ${ }^{10}$ Namun, karena pada penelitian ini kandungan lemak western fast food yang dikonsumsi hanya sedikit, ini akan berdampak terhadap kontribusi asupan lemak sehari yang juga rendah, sehingga menyebabkan tidak adanya hubungan secara statistik.

Kandungan natrium pada western fast food yang dikonsumsi subjek berkisar antara 0,60 $809,90 \mathrm{mg} / \mathrm{hari}$ dengan median 163,40 mg/hari. Hasil uji bivariat menunjukkan bahwa tidak ada hubungan bermakna antara kandungan natrium pada western fast food yang dikonsumsi dengan tekanan darah sistolik maupun diastolik. Hal ini disebabkan oleh faktor sensitifitas dalam merespon natrium yang diturunkan secara genetik pada individu berbeda-beda. Penelitian pada remaja di Amerika menyebutkan bahwa remaja yang memiliki riwayat hipertensi dalam keluarga lebih sensitif terhadap natrium. Penambahan $1000 \mathrm{mg}$ $\mathrm{NaCl}$ dalam diit remaja yang memiliki riwayat hipertensi keluarga mampu menaikkan tekanan darahnya, sedangkan remaja yang tidak ada riwayat keluarga hipertensi tekanan darahnya tetap normal. ${ }^{28}$ Dalam penelitian ini, lebih dari $50 \%$ subjek tidak memiliki riwayat hipertensi pada keluarga. Selain itu, kandungan natrium western fast food yang dikonsumsi rendah yaitu 163,40 $\mathrm{mg} /$ hari dan kontribusi natrium western fast food yang dikonsumsi terhadap pemenuhan kebutuhan sehari yaitu $16,37 \%$ sehingga pada penelitian ini subjek lebih banyak memiliki tekanan darah normal dibanding yang memiliki tekanan darah tinggi.

Kandungan serat pada western fast food yang dikonsumsi subjek berkisar antara $0,00-1,4 \mathrm{gr} / \mathrm{hari}$ dan rata-rata kontribusi western fast food pada subjek 1,29 $\mathrm{gr} / \mathrm{hari}$. Ini menunjukkan bahwa kandungan serat pada western fast food sangat rendah dan kontribusi pada pemenuhan kebutuhan sehari tidak mencukupi kebutuhan.Hasil uji bivariat menunjukkan tidak adanya hubungan secara bermakna antara serat dan kontribusi gizi serat western fast food yang dikonsumsi dengan tekanan darah sistolik maupun diastolik.Pada penelitian 
ini serat yang rendah pada western fast food tidak ada hubungan dengan hipertensi. Hal ini mungkin disebabkan pada penelitian ada beberapa faktor protektif terhadap hipertensi, seperti riwayat keluarga hipertensi serta gizi lebihyang juga rendah.

Kelemahan pada penelitian ini adalah metode dalam mengambil data kuesioner kurang mendalam karena perhitungan konsumsi western fast food hanya di restoran tidak di tempat lain, serta alat yang digunakan dalam mengukur tekanan darah belum ditera. Hal ini mungkin merupakan beberapa faktor yang menyebabkan pada penelitian ini tidak berhasil membuktikan adanya hubungan konsumsi western fast food dengan hipertensi.

\section{SIMPULAN}

Subjek yang mengkonsumsi western fast food sering sebanyak 10 orang $(22,2 \%)$.Tidak terdapat hubungan konsumsi western fast food dengan hipertensi pada remaja.

\section{SARAN}

Saran untuk remaja agar memantau berat badan secara rutin untuk menghidari kejadian obesitas dan hipertensi. Saran untuk penelitian selanjutnya agar meneliti berbagai macam faktor risiko (misal: pengetahuan gizi terkait western fast food) terhadap kejadian hipertensi pada anak sekolah menengah atas dengan jumlah subjek penelitian yang lebih banyak dan desain rancangan lain, seperti case control.

\section{DAFTAR PUSTAKA}

1. Yogiantoro M. Buku Ajar Ilmu Penyakit dalam. 1st ed. Jakarta: Pusat Penerbitan Ilmu Penyakit Dalam FKUI: 2007; 599-603.

2. Ross CB, Patrick LR, James RD, High BloodPressure in Chronic Disease Epidemiology and Control. SecondEdition,American Public Health Assosiation: 262-264.

3. Mosterd A, D'Agostino RB, Silbershatz H, Sytkowski PA, Kannel WB, Grobbee DE. et.al. Trends in the Prevalens of Hypertension, Antihypertensive terapy, and left Ventricular Hypertrophy from 1950 to 1989. 1999; 1221-1222.

4. Kearney PM, Whelton M, Reynolds K, Muntner P, Whelton PK, He J. Global Burden of Hypertension: Analysis of Worldwide Data. New Orleans: The Lancet, 2002; 217, 221-222

5. Raymond JL, Couch SC.Krause's Food and the Nutrition Care Process. In: Mahan LK, Escottstump S, Raymond JL.Medical Nutrition Therapy for Cardiovascular Disease. 13th ed. Canada: Elsevier; 2012. P. 742-78.

6. Badan Penelitian dan Pengembangan Kesehatan Kementerian Kesehatan RI. Riset Kesehatan Dasar Tahun 2013. Jakarta; 2013
7. Dinas Kesehatan, Profil kesehatan kota semarang. 2010http://www.dinkeskotasemarang.go.id/?p=halaman mod\&jenis=profi 1

8. Badan Penelitian dan Pengembangan Kesehatan. Riset Kesehatan Daerah (RISKESDAS) 2013. Departemen Kesehatan Indonesia; 2013

9. Diamond JA, Phillips RA. Hypertensive Heart Desease, Hypertens Res; 2005

10. Manurung E. Hubungan antara asupan lemak tak jenuh tunggal dengan kadar kolesterol HDL Plasma penderita penyakit jantung koroner. [Tesis]. Program Magister Sains Ilmu Gizi Klinik Universitas Indonesia; 2004

11. Saing, Johannes H. Hipertensi Pada Remaja. Jurnal Sari Pediatri;2005. p. 159-165

12. King DE, Mainous AG, Egan BM, Woolson RF, Geesey ME. Fiber and C-Reactive Protein in Diabetes, Hypertension, and Obesity. Diabetes Care; 2005. p. 28:6

13. Banowati L, Nugraheni, Niken P. Risiko Konsumsi Western Fast Food dan Kebiasaan Tidak Makan Pagi Terhadap Obesitas Remaja Studi di SMAN 1 Cirebon. Media Medika Indonesiana; 2011

14. Yogiantoro M. Hipertensi Esensial. Buku Ajar Ilmu Penyakit Dalam. 1st ed. Jakarta: FKUI; 2006

15. Anwar TB. Dislipidemia sebagai faktor resiko penyakit jantung koroner, medan : FK USU; 2004

16. Thompson JL, Manore MM, Voughan LA. Science of Nutrition. 2nd ed. USA: Pearson Education Inc.; 2011.p.126-7, 345

17. Novitasari. Kebiasaan Mengonsumsi Western Fast Food Pada Remaja SMU yang Berstatus Gizi Normal dan Obese di Kota Bogor. [skripsi]. Jurusan Gizi Masyarakat dan Sumberdaya Keluarga, Fakultas Pertanian, Institut Pertanian Bogor; 2005

18. Virgianto, Gregorius and Purwaningsih, Endang. Konsumsi Fast Food Sebagai Faktor Risiko Terjadinya Obesitas pada Remaja Usia 15-17 Tahun.Media Medika Muda (M3);2006 : ISSN 1858-3318

19. Khomsan A. Pangan dan Gizi untuk Kesehatan. Jakarta: PT Rajagrafindo Persada; 2004

20. Intan NR. Faktor-faktor yang berhubungan dengan obesitas

berdasarkan persen lemak tubuh pada remaja di SMA islam terpadu Nurul Fikri Depok.[Skripsi]; 2008

21. Eneng E. Hubungan antara Rasio Lingkar Pinggang-Pinggul dan Kebiasaan Mengkonsumsi Makanan Olahan terhadap Kejadian Hipertensi pada Pasien Rawat Jalan di Rumah Sakit Panti Rapih Yogyakarta. [Skripsi]. Yogyakarta: Program Studi S-1 Gizi Kesehatan Fakultas Kedokteran Universitas Gajah Mada; 2007

22. Saing JH. Hipertensi Pada Remaja. Jurnal Sari Pediatri;2005: 159-165 
23. National Institutes of Health National Heart, Lung, and Blood Institute. The Fourth Report On The: Diagnosis, Evaluation, and Treatment of High Blood Pressure in Children and Adolescents. NIH Publication; 2005:05-5267

24. Hadju V. Gizi dan Penyakit Degeneratif. [skripsi]. Makasar: FKM Universitas Hasanudin; 2003

25. Gu D, Wildman RP, Wu X, Reynolds K, Huang J, Chen CS, He J. Incidence and predictors of hypertension over 8 years among Chinese men and women. Journal of Hypertension;2007

26. Tri FF. Hubungan Antara Indeks Massa Tubuh (IMT), Aktivitas Fisik Dan Kebiasaan Mengkonsumsi Makanan Siap Saji Ala Barat Dengan Tekanan Darah Pada Pensiunan Pegawai PT. Pertamina Semarang. Semarang: Universitas Diponegoro; 2008

27. Mihrete K. Association Between Fast Food Consumption and Obesity ang High Blood Pressure Among Office Workers [dissertation]. Walden Univ; 2012

28. Falkner B, Michel S. Blood pressure response to sodium in children and adolesencents. Am J Clin Nutr [serial online] 1997 [cited 2015 August 18]; 85: 618-21. Available from: URL: HYPERLINK http://www.ajen.org 